\title{
Gümüşhane İli Kamu Binalarındaki Isı Yalıtımı Uygulamalarının İncelenmesi
} Examining Heat Insulation Applications on Public Buildings in Gümüşhane

\author{
Birol ŞAHIN ${ }^{* 1, a}$, Cenk ÇARKACI ${ }^{2, b}$ \\ ${ }^{I}$ Recep Tayyip Erdoğan Üniversitesi, Makine Mühendisliği Bölümü, 53100, Rize \\ ${ }^{2}$ Çevre ve Şehircilik İl Müdürlü̆̈̈̈, 29000, Gümüşhane
}

• Geliş tarihi / Received: 15.02.2019 • Düzeltilerek geliş tarihi / Received in revised form: 11.04.2019 • Kabul tarihi / Accepted: 02.05.2019

Öz

Günümüzde ilerleyen teknolojiye bağlı olarak kişi başı enerji ihtiyacı da hızla artmaktadır. Artan enerji ihtiyacını karşılamanın yollarından biri enerji üretimini artırmakken diğeri ise tüketilen enerjiden tasarruf etmektir. Özellikle 1973 yılı sonrasında yaşanan enerji kriziyle birlikte enerjinin verimli kullanılması önem kazanmıştır. Ülkemizde konutlarda daha çok 1sıtma ve soğutma uygulamalarında kullanılan enerjiden tasarruf etme potansiyeli oldukça yüksektir. Kışların uzun ve soğuk olduğu bölgelere sahip olan ülkemizde özellikle ısıtma uygulamalarında elde edilecek bu enerji tasarrufu hem ülke ekonomisi için hem de çevre kirliliğini azaltmak için oldukça önemlidir. Yapılan çalışmada, Gümüşhane ili sınırları içerisinde bulunan bir kamu binası (lojman) için 1Sı yalıtımsız ve 1sı yalıtımlı durumlar incelenerek, yapılan yalıtım uygulamalarının TS 825 standartlarına göre yeterliliği araştırılmıştır. Binanın 1Sı yalıtımlı ve 1sı yalıtımsız termal görüntüleri alınarak binada oluşan 1sı köprüleri belirlenmiştir. Çalışma sonucunda binada uygulama projesinde bulunan yalıtımın TS 825 standartlarına göre yeterli olmadığı, bu nedenle enerji tasarrufunda kayıplar olduğu görülmüştür. Ayrıca standartlara göre uygulanan yalıtımla birlikte \% 50’lere varan bir tasarruf sağlanacağı elde edilmiştir.

Anahtar kelimeler: Enerji tasarrufu, Isı köprüsü, Isı yalıtımı

\begin{abstract}
Energy need per person is increasing rapidly due to advancing technology nowadays. One of the ways to meet the increasing energy needs is to increase energy production while the other one is to conserve energy consumed. Especially with the energy crisis experienced after 1973, the efficient use of energy has gained importance. In our country, the energy saving potential used in heating and cooling applications in houses is quite high. This energy saving which will be obtained especially in heating applications in our country which has regions with long and cold winters is very important both for the country economy and for reducing the environmental pollution. In this study, uninsulated and insulated conditions of a public building (lodging) located in Gümüşhane were examined and the adequacy of the insulation applications was investigated according to TS 825 standards. Insulated and uninsulated thermal images of the building were taken and heat bridges formed in the building were determined. The results of the study show that insulation in the application project in the building is not sufficient according to TS 825 standards and therefore there are losses in energy saving. In addition, it is seen that saving can be achieved up to 50\% with insulation applied according to the standards.
\end{abstract}

Keywords: Energy saving, Heat bridge, Heat insulation

\footnotetext{
*a Birol ŞAHIN; birol.sahin@erdogan.edu.tr; Tel: (0464) 2238518; orcid.org/0000-0003-1004-4720

${ }^{\mathrm{b}}$ orcid.org/0000-0003-2051-3375
} 


\section{Giriş}

Geçmişten günümüze kadar insanların 1sıl yönden yaşamlarını sağlıklı bir şekilde yürütebilmeleri amacıyla çok farklı uygulamalar yapılmıştır. Ateşin bulunmasıyla başlayan bu serüven, ilerleyen y1llarla birlikte yerini ocak ve soba gibi elektrik veya fosil yakıt kaynaklı 1sitma sistemlerine bırakmıştır. İnsanların yaşamlarını sürdürecekleri iç ortam 1sı1 konfor koşulları; sıcaklık, nem, hava akım hızı ve radyant 1s1 gibi ana bileşenlerden oluşmakla birlikte iç ortam sıcaklık değerini belirlemede bu bileşenlerin yanı sıra ortamda yürütülen işin niteliği, kişinin fiziki ve ruhi yapısı, kişinin sağlık ve giyim durumu ile beslenme durumu gibi faktörlerde etkili olmaktadır. Görüldüğü gibi ısıl konfor şartlarının oluşturulması için iç ortamın 1sittlması veya soğutulması başta olmak üzere çok farklı uygulamalar yapılabilmektedir. $\mathrm{Bu}$ uygulamaları yapabilmek için de enerjiye ihtiyaç vardır. Gerekli enerji kaynağı ise bazı özel uygulamalar dışında ya elektrik, ya da fosil yakıt kökenli olmaktadır. İlerleyen teknoloji ve artan kişi başı enerji tüketim değerlerine bağlı olarak enerji ihtiyacı da artmaktadır. Günümüzdeki enerji üretim prosesleri düşünüldüğünde gerekli enerjinin elde edilmesi büyük oranda fosil yakitlara (kömür, doğalgaz, vb.) bağlıdır. Ülkemiz fosil yakıtlar açısından yeterli kaynaklara sahip değildir. $\mathrm{Bu}$ nedenle enerji üretimi, hammadde açısından büyük oranda dışa bağımlıdır. 2018 yılı Ekim ayı verilerine göre enerji tüketim yüzdeleri incelendiğinde en çok tüketim sırasıyla \% 45 doğal gaz, \%26 elektrik ve \%21 motorin olarak ortaya çıkmaktadır. 2018 yılı Ekim ayına ait enerji raporuna göre elektrik enerjisi üretimindeki kaynakların payına bakıldığında \%35 doğal gaz, $\% 25$ ithal kömür, $\% 17$ linyit, $\% 8$ hidrolik santral (akarsu), \%6 rüzgâr ve \%3 hidrolik santral (barajl1) sonucu ortaya çıkmaktadır (URL-1, 2018). Kullanılan enerjinin sektörel dağılımında ise 2004 y1lı verilerine göre \%41.7'si sanayi, \%30.4'ü konut, \%20'si ulaştırma başlıca alanlar olarak karşımıza çıkmaktadır. Binalarda tüketilen enerjinin büyük bir kısmı da 1sıtma-soğutma işlemlerine harcanmaktadır. Bu nedenle binalarda standartlara uygun yapılacak isı yalıtımı, tüketilen enerji miktarında önemli bir azalmaya sebebiyet verecektir. Dünya Bankası tarafindan 2010 yılında hazırlanan taslak rapora göre konutlarda elektrik açısından \%29, yakıt açısından \%46 civarında bir tasarruf potansiyeli bulunmaktadır. Ayrıca kişi başı enerji yoğunluğu düşürülerek enerjide tasarruf sağlanabilmektedir. Ülkemizde enerji tasarruf potansiyelinin yüksek olduğu konut 1sıtmasıyla ilgili özellikle farklı yalıtım malzemesi ve yakıt kullanımına bağlı olarak yapılan çalışma sayısı son yıllarda artmıştır. Kaynaklı ve Karadeniz (2007) örnek bir bölgenin 1sitma sezonunu tespit ederek enerji maliyetleriyle birlikte optimum yalıtım kalınlığını bulmuşlardır. Duvar tipine, yalitım malzemesinin 1s1 iletim katsayına ve bölgenin derece-gün sayısına bağlı olarak gerekli yalıtım kalınlıklarının değişimini analiz etmişlerdir. Çalışma sonucunda duvarın toplam 1S1 transfer katsayısının artmasiyla optimum yalıtım kalınlığının azaldığı, derece-gün sayıs1 ve yalıtım malzemesinin 1sil iletkenlik değerinin artmasıyla birlikte optimum yalıtım kalınlığının da arttığını bulmuşlardır. Kürekçi vd. (2009) bina diş duvarına ait optimum yalıtım kalınlığı değerini İzmir, İstanbul, Ankara ve Erzurum illeri için altı farklı yakıt tipi ve iki farklı yalıtım malzemesi için geri ödeme süreleriyle birlikte hesaplayarak birbirleriyle karşılaştırmışlardır. Sonuç olarak çevreye olan etkileri de göz önüne alınarak doğal gazın yakıt olarak kullanıldığı optimum yalıtım kalınlığ değerleri belirlenmiştir. Gürel ve Cingiz (2000) farklı yapı malzemeleri (yatay delikli tuğla ve gaz beton) ve yalıtım şekilleriyle yalıtılmış (dıştan yalıtım ve sandviç yalıtım) bir bina dış duvarını model almışlardır. Çalışmada söz konusu duvardan gerçekleşen 1s1 kayb1 mevcut hesaplamalar yoluyla belirlenmiş ve ömür-maliyet analizine göre optimum 1sı yalıtım kalınlıkları, geri ödeme süreleri ve enerji tasarrufları belirlenmiştir. Sezer (2005) ülkemizde uygulaması yaygın olan duvarların dış yüzeyine, iç yüzeyine, çift duvar arasına ve havalandırmalı dış duvar yalıtım uygulamalarını inceleyerek hesaplanan toplam 1sı kaybı değerlerinin TS 825'e göre izin verilen değerlerin üzerinde olduğunu bulmuştur. Çalışmada ayrıca yalıtım sistemi seçilirken dikkat edilmesi gereken hususlardan bahsedilmiştir. Aktemur ve Atikol (2017) yaptıkları çalışmada Türkiye'nin dört farklı iklim bölgesinde bulunan Muğla (1.Bölge), Kocaeli (2.Bölge), Ankara (3.Bölge), ve Ardahan (4.Bölge) illeri için altı farklı yakıt türü ve yalıtım malzemesi için on beş yıllık bir süre boyunca meydana gelen enerji tasarrufu ve amortisman sürelerini TS 825 standardina göre incelemişlerdir. En büyük enerji tasarrufunu LPG yakıtının sağladığı görülmüştür. Balo vd. (2011) tarafından yapılan çalışmada dört iklim bölgesinden birer şehir (İzmir, Diyarbakır, Uşak, Bayburt) için binaların dış duvarlarında kullanılan yalıtım malzemesinin optimum kalınlığının belirlenmesinde, enerji maliyetlerine bağlı derecegün metodu, termoekonomik optimizasyon metodu, TS 825 standardı olmak üzere üç farklı metot kullanılmıştır. Çalışma sonucunda yalıtım 
kalınlığı, enerji kazancı ve geri ödeme süresine ilişkin bilgiler sunulmuştur. Buyruk vd. (2013) delikli tuğladan iki odalı olarak inşa edilen bir binadaki yalıtımın içten, dıştan ve sandviç olarak uygulanması durumuna ait termal kamera görüntülerini ve ara yüzey sıcaklık değerlerini belirleyerek bir paket program yardımıyla elde edilen sonuçları karşılaştırmışlardır. Isı kaybının nedeni olarak kolon ve kirişlerdeki 1sı köprüleri gösterilmiştir. Karakoç (2015) yaptığı çalışmada yakıt olarak doğal gazın kullanıldığı bir binada sırasıyla taş yünü, neopor ve genleştirilmiş polistrenin kullanılması durumunda ortaya çıkan optimum yalıtım kalınlıklarını belirlemiştir. Yııllık 1sitma gereksinimleri, son altı yıla ait ortalamay içeren 1sıtma derece-gün sayısına göre hesaplanmıştır. Yaman vd. (2015) tarafından yapılan çalışmada binalardaki yapı bileşenlerinde uygulanan farklı 1s1 yalıtımı türleri ve kullanılan malzemeler hakkında bilgi verilerek ilgili mevzuat ve hesaplama yöntemlerinden bahsedilmiştir. Türkmen (2016) oldukça fazla sayıda örneklem grubuna ait bina kabuğundaki 1s1 yalıtımı uygulamaları, yapım aşamasında karşılaşılan sorunlarla birlikte ele alınarak enerji performansını önemli ölçüde etkileyen 1S1 köprüleri, yetersiz yalıtım ve yoğuşma gibi parametreleri incelemiştir. Ertürk (2016) Ankara'da bulunan binalar için iki farklı yakıt türü, üç farklı yalıtım malzemesi ve dört farklı kalınlıktaki hava boşluğunun optimum yalıtım kalınlığına, amortisman süresine ve kişi başı yakıt tüketimi emisyonuna etkisini incelemiştir. Kürekçi vd. (2012) ülkemizdeki 81 il için iki farklı yakıt türü ve beş farklı yalıtım malzemesinin kullanıldığı dört ana bileşenden oluşan dıştan yalıtılmış bir duvar için optimum yalıtım kalınlığı, geri ödeme süresi ve metrekare başına tasarruf miktarlarını belirlemek için kapsamlı bir çalı̧̧ma yapmışlardır. Karakaya (2018) dört farklı duvar tipi, üç farklı yakıt türü ve iki farklı yalıtım malzemesi kullanarak 1sitma ve soğutma prosesleri için optimum yalıtım kalınlığı, geri ödeme süresi, enerji tasarrufu ve toplam maliyete göre çevreye yaymış oldukları emisyon değerlerini bularak birbirleriyle karşılaştırmıştır. Yalıtım kalınlığının artışı enerji sarfiyatını azaltmasına rağmen optimum değerden sonraki yalıtım kalınlıklarının toplam maliyeti artırdığ bulunmuştur. Ertürk vd. (2018) çalışmada İzmir ilindeki bir bina dış duvarında üç farklı yalıtım malzemesi ve üç farklı yakıt kullanılması durumunda optimum yalıtım kalınlığı, geri ödeme süresi, toplam maliyet, sera gazı emisyon salınımı ve enerji tasarrufu parametrelerini ömür-maliyet analizi yöntemine göre birbirleriyle karşılaştırmışlardır. Seçilen duvar tipi için en düşük yalıtım kalınlığı XPS yalıtım malzemesinde ve yakıt olarak doğalgaz kullanılması halinde ortaya çıkmıştır. Kon ve Yüksel (2016) Balıkesir ilindeki iki binaya ait optimum yalıtım kalınlığı, geri ödeme süreleri ve enerji tüketim değerlerini derece-gün ve ömür-maliyet analizine göre dokuz farklı yalıtım malzemesi için doğal gaz yakıtının kullanıldığı durumda elde etmişlerdir. Optimum yalıtım kalınlığg en düşük olan yalıtım malzemesi XPS olarak belirlenmiştir.

Özellikle 1973 yılında ortaya çıkan petrol krizi nedeniyle petrole dayalı enerji üretiminin yerine enerji kaynaklarının çeşitlendirilmesi amaçlanmış ve böylece yenilenebilir enerji kaynaklarıyla ilgili yeni teknolojik gelişmeler ortaya çıkmaya başlamıştır. Petrole bağlı enerji üretimi yapan ülkeler için petrole bağlı üretimin azaltılması amacıyla enerjinin çeşitlendirilmesinin yanında var olanın enerjinin verimli kullanımı da ön plana çıkmıştır. Bu nedenle özellikle son yıllarda enerji verimli cihazların kullanılması ve 5627 sayılı "Enerji Verimliliği Kanunu" ile binalarda enerji kimlik belgesinin oluşturularak enerjinin verimli kullanılması amaçlanmıştır. Ancak, gerek kanunda belirtilen prosedürlere uyulmamas1, gerekse uygulama (montaj) kaynaklı hatalar nedeniyle istenilen enerji tasarrufu her zaman için sağlanamamaktadır.

Yapılan çalışmada Gümüşhane ili sınırları içerisinde bulunan bir kamu binası (lojman) için 1S1 yalıtımı yapılmadan önceki enerji gereksinimi ile 1S1 yalıtımı yapıldıktan sonraki enerji gereksinimi değerleri TS 825 standartlarına göre (URL-2, 2018) hesaplanarak elde edilen sonuçlar karşılaştırılmıştır.

\section{Teorik Çalışma}

İnceleme konusu olan kamu binas1 (lojman) Gümüşhane ili sınırları içerisinde 1988 yılında yalıtımsız olarak inşa edilmiş olup, 2014 yılında dıştan mantolama yapılarak yalıtımlı hale getirilmiştir. Binayı dişardan sararak 1S1 köprülerini azaltması, iç mekanda alan kaybı oluşturmaması, yapının betonarme elemanlarını dış etkilerden koruması ve eski yapılarda uygulamasının daha basit olması sebebiyle dıştan mantolama tercih edilmiştir. Çalışmada binanın yalıtımsız hali, yalıtım yapıldıktan sonraki mevcut hali ve TS 825 'e göre olmas1 gereken yalıtımlı hali için incelemeler yapılmıştır. Çalışmada ilk olarak binanın bu üç durumu için yapı katmanlarının ve yapilan yalıtımın, TS 825 standardına göre yeterli olup olmadığ belirlenmiştir. Ayrıca binanın yalıtımsız ve 
yalıtımlı durumu için alınan termal kamera görüntüleri üzerinden inceleme ve irdeleme yapılmıştır. Örnek bina, Gümüşhane Üniversitesine ait Yenimahalle Kazım Karabekir Caddesinde bulunan lojman binasıdır. Binaya ait bilgiler aşağıda verilmiştir:

Binanın bulunduğu şehir

Binanın yapım yılı

: GÜMÜŞHANE

Diş ortam sıcaklığı

$: 1988$

$:-12^{\circ} \mathrm{C}$

Binanın bulunduğu iklim bölgesi

: 4.Bölge

Bina, bodrum, zemin ve 3 normal kattan oluşmakta ve ayrık nizamdadır. Binada bodrum katta 1, diğer katlarda 2'şer olmak üzere toplam 9 daire bulunmaktadır. Binanın ön ve yan görünüşleri Şekil 1 ve Şekil 2 de, bodrum kat planı Şekil 3 te, zemin kat planı Şekil 4 te ve normal kat planı Şekil 5 te verilmiştir.

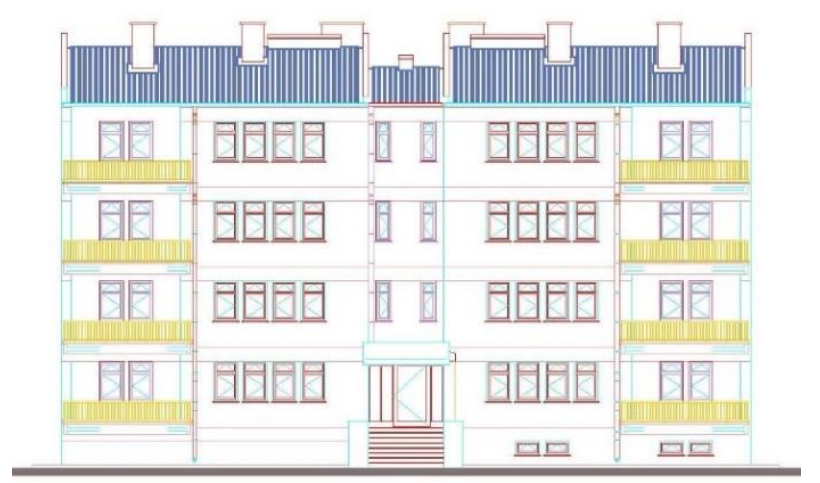

Şekil 1. Örnek binanın ön görünüşü
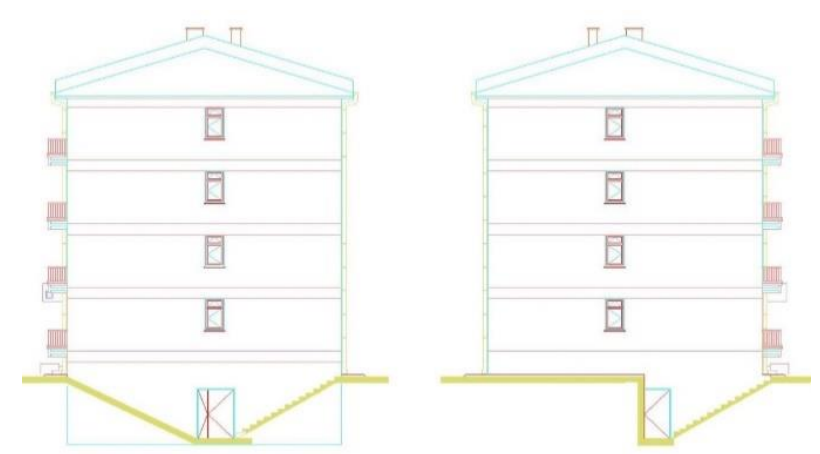

Şekil 2. Örnek binanın yan görünüşleri

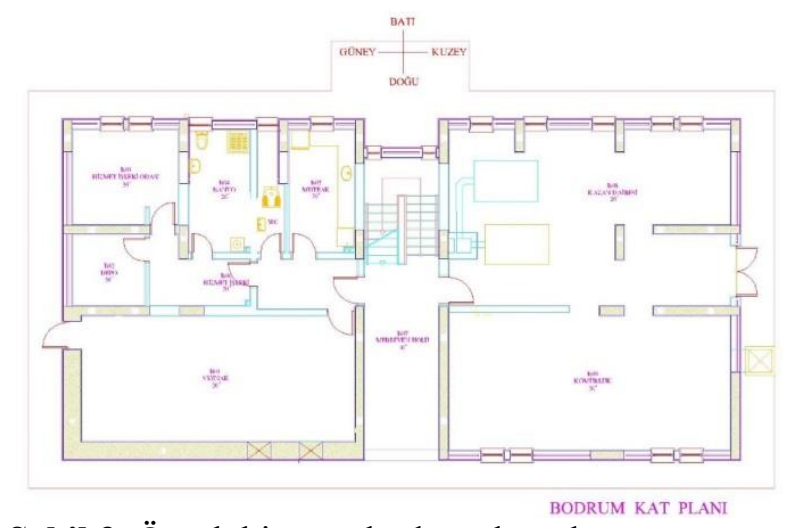

Şekil 3. Örnek binanın bodrum kat planı
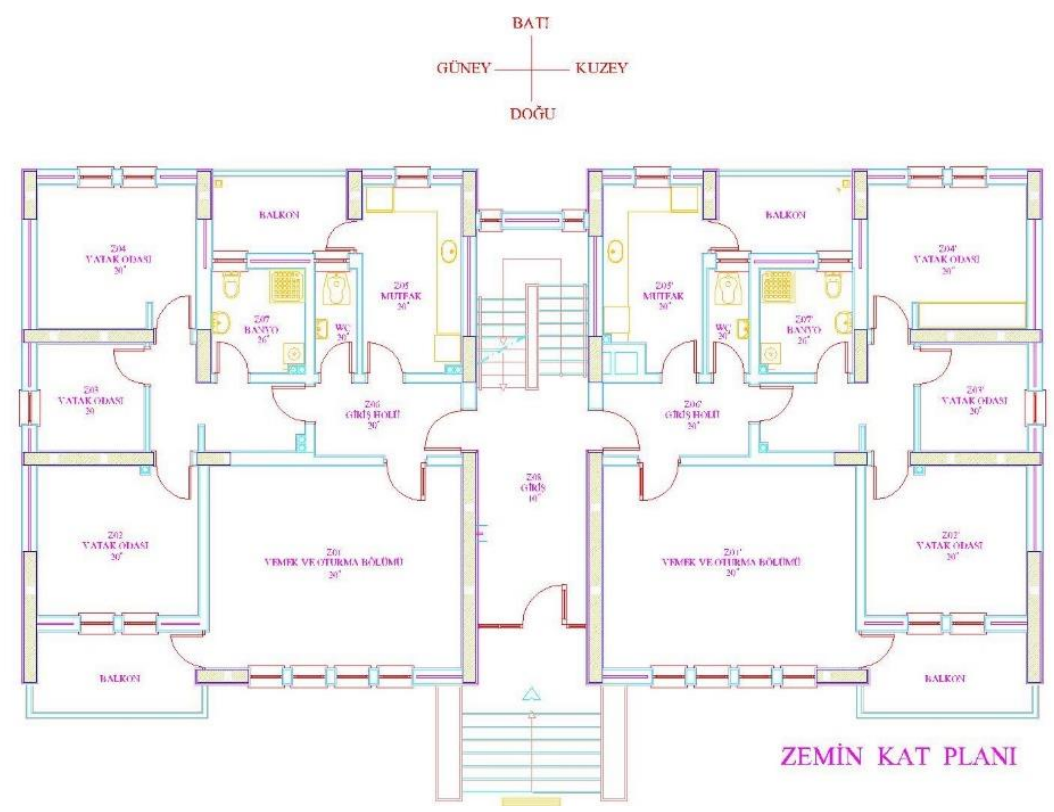

Şekil 4. Örnek binanın zemin kat planı 

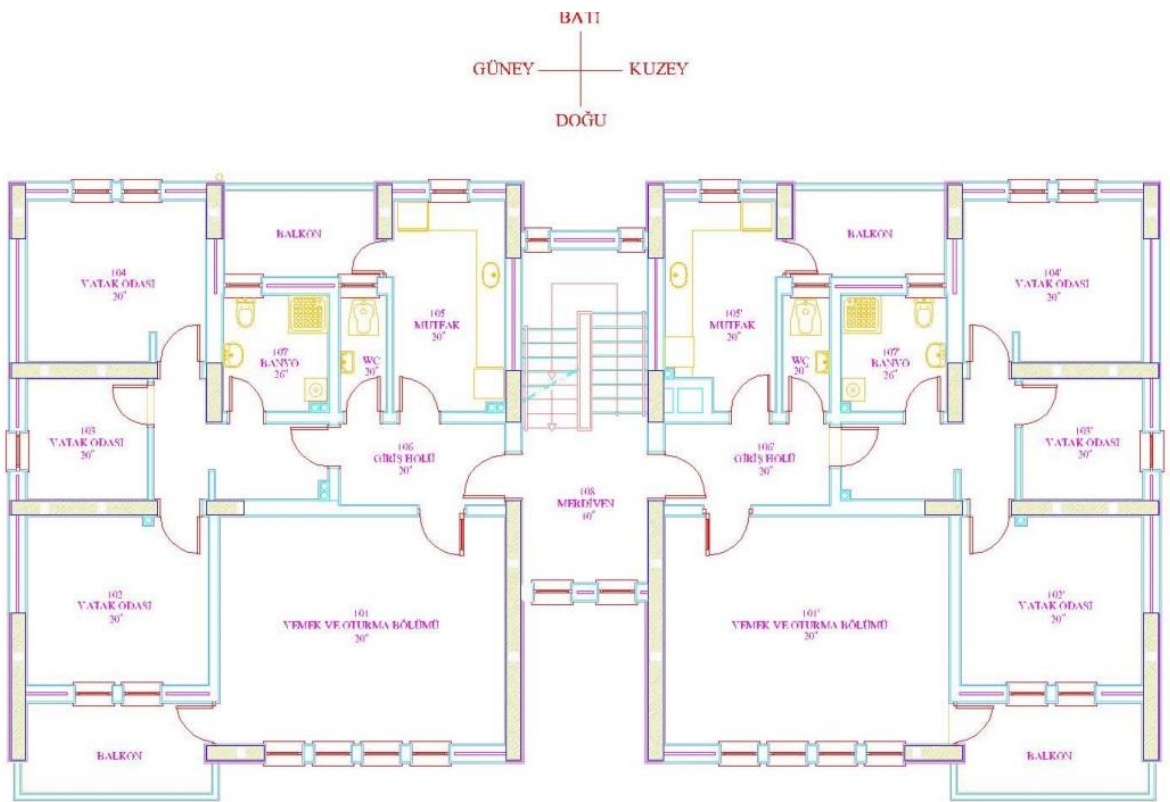

1-2-3 KAT PLANI

Şekil 5. Örnek binanın normal kat planları

Örnek binaya ait dış duvarı oluşturan bileşenler yalıtımsiz, mevcut yalitımlı ve TS 825 e uygun olarak Şekil 6 da verilmiştir. Örnek binada Şekil 6.a'da görüldüğü gibi yalıtımsız durum için yatay delikli tuğlalar arasında $4 \mathrm{~cm}$ lik hava boşluğu bulunmaktadır. Uygulanan yalıtımla birlikte bina dış yüzeyine yapılan mantolamayla $5 \mathrm{~cm}$ lik XPS eklenmiştir. Ancak yapılan hesaplamalar sonucu TS 825 'e göre bu yalıtımın yeterli olmadığ 1 , yalıtım kalınlığının $7 \mathrm{~cm}$ ye çıkarılması gerektiği elde edilmiştir.

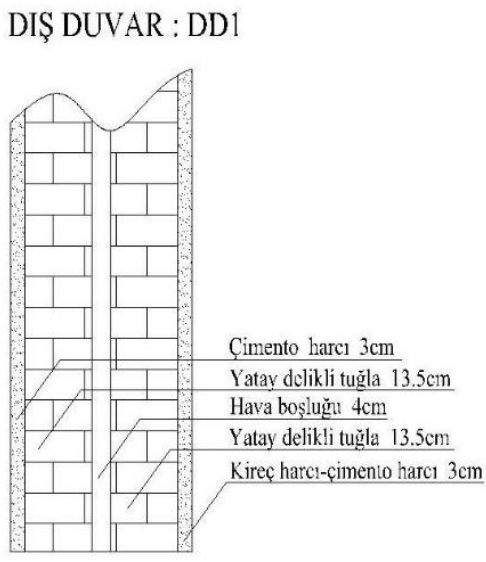

a)

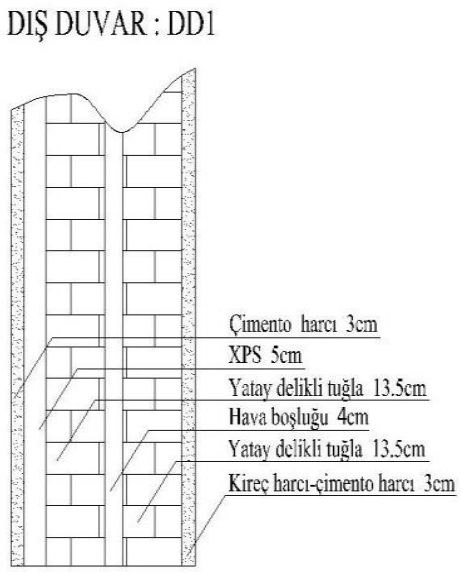

b)

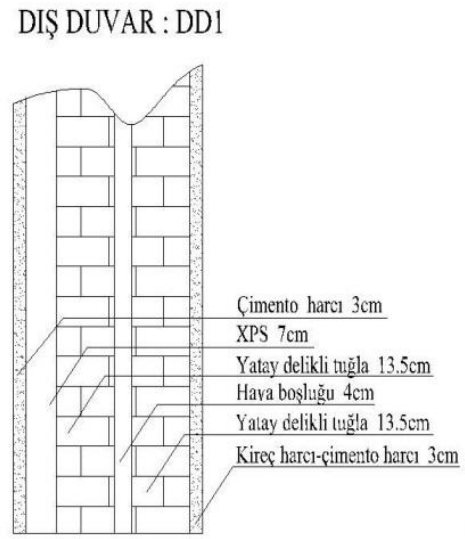

c)

Şekil 6. Örnek binanın yapı elemanları (a) Yalıtımsız durum (b) Mevcut yalıtımlı durum (c) TS 825' e göre yalitımlı durum

Şekil 6 da verilen çok katmandan oluşan bir duvar için 1 s1l iletim direnci R;

$R=\frac{d_{1}}{\lambda_{h 1}}+\frac{d_{2}}{\lambda_{h 2}}+\cdots \frac{d_{n}}{\lambda_{h n}}$ denklemi yardımıyla elde edilir. Denklem 1 de yap1 elemanı kalınlıkları d ve bu yap1 elemanlarına ait 1sil iletkenlik hesap değeri $\lambda_{\mathrm{h}}$ ile gösterilmekte ve TS 825 standartlarından seçilmektedir. Her bir katmana ait 1 sıl geçirgenlik direnç değerleri hesaplanarak yapıyı oluşturan duvar, tavan ve döşeme gibi elemanlara ait toplam 
1sıl geçirgenlik direnci (1/U) aşağıdaki gibi belirlenir:

$Q=U \cdot A \cdot\left(\theta_{i}-\theta_{e}\right)$

$\frac{1}{U}=R_{i}+R+R_{e}$

Denklem 2 de verilen $R_{i}$ iç yüzeyin yüzeysel ısıl iletim direncini $\left(\mathrm{m}^{2} . \mathrm{K} / \mathrm{W}\right)$ ve $\mathrm{R}_{\mathrm{e}}$ dış yüzeyin yüzeysel ssıl iletim direncini $\left(\mathrm{m}^{2} . \mathrm{K} / \mathrm{W}\right)$ göstermektedir. Yüzeysel 1sıl iletim direnci değerleri hesaplanan yap1 bileşenine göre minimum değeri 0 maksimum değeri 0.17 olacak şekilde TS 825 ten seçilmektedir. Yapı bileşenine ait 1s1 kayb1 değeri ise denklemi yardımıyla elde edilir. Denklem 3 te görülen $\theta_{\mathrm{i}}$ iç ortam sıcaklık değerini, $\theta_{\mathrm{e}}$ dış ortam sıcaklık değerini göstermektedir. Yukarıda verilen Denklem 1 ve 2 yardımıyla yapı bileşenlerine ait 1sıl iletim direnç değerleri ve 1 sıl geçirgenlik dirençleri hesaplanarak belirlenen her bir hacme ait 1sı kaybı değerleri Denklem 3 yardımıyla elde edilmiş ve üçüncü kata ait örnek bir hacim için çizelge 1 de verilmiştir.

Çizelge 1. Örnek bir hacme ait 1sı kaybı hesabı çizelgesi.

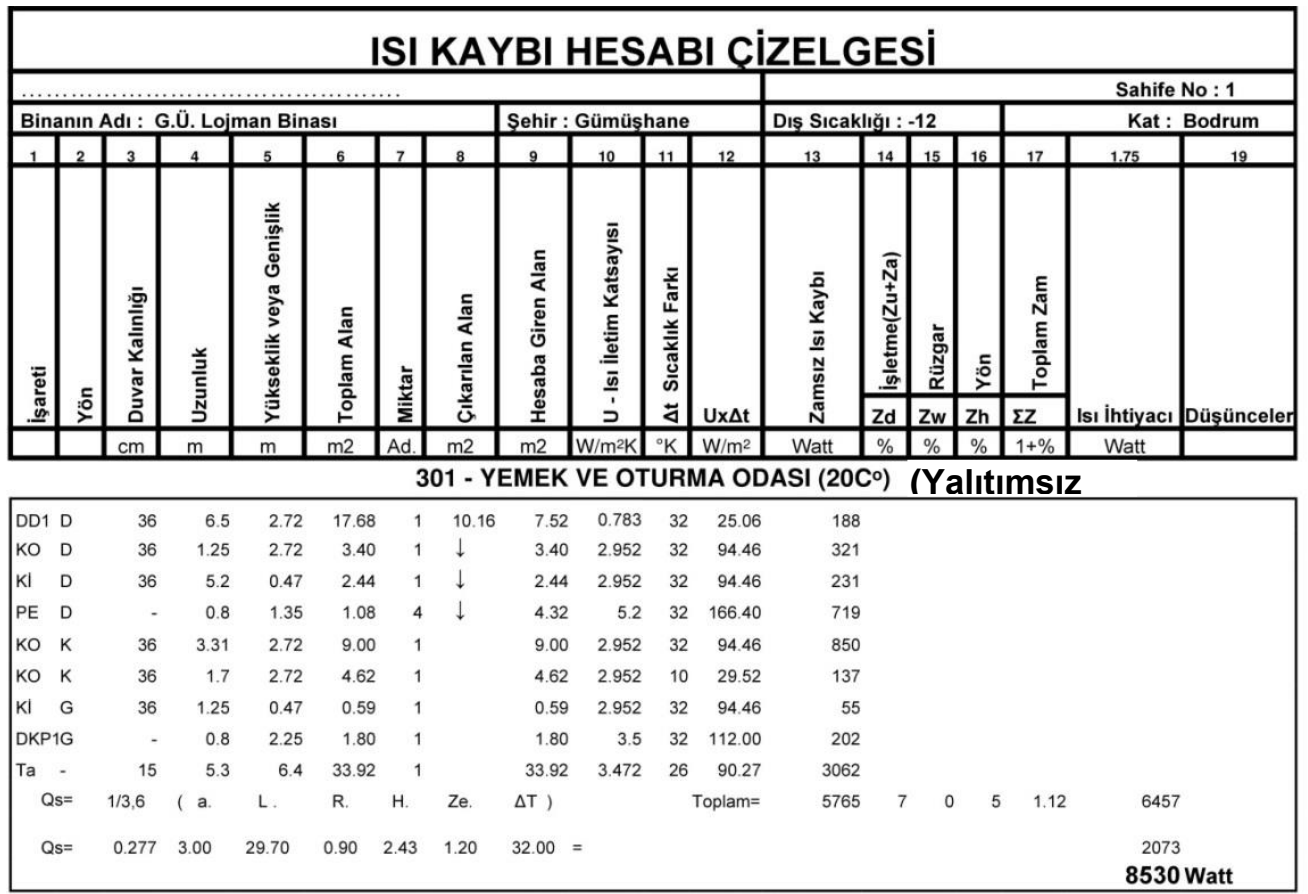

\begin{tabular}{|c|c|c|c|c|c|c|c|c|c|c|c|c|c|c|c|c|}
\hline & & & & & & $01-Y E$ & EMEK & VE OT & JRN & MA OD & $\left(20 \mathrm{C}^{\circ}\right.$ & ( & le & & & llıtımlı \\
\hline DD1 D & 36 & 6.5 & 2.72 & 17.68 & 1 & 10.16 & 7.52 & 0.34 & 32 & 10.88 & 82 & & & & & \\
\hline KO D & 36 & 1.25 & 2.72 & 3.40 & 1 & $\downarrow$ & 3.40 & 0.499 & 32 & 15.97 & 54 & & & & & \\
\hline KI D & 36 & 5.2 & 0.47 & 2.44 & 1 & $\downarrow$ & 2.44 & 0.499 & 32 & 15.97 & 39 & & & & & \\
\hline PE D & - & 0.8 & 1.35 & 1.08 & 4 & $\downarrow$ & 4.32 & 3 & 32 & 96.00 & 415 & & & & & \\
\hline KO $\mathrm{k}$ & 36 & 3.31 & 2.72 & 9.00 & 1 & & 9.00 & 0.499 & 32 & 15.97 & 144 & & & & & \\
\hline KO $\mathrm{k}$ & 36 & 1.7 & 2.72 & 4.62 & 1 & & 4.62 & 0.499 & 10 & 4.99 & 23 & & & & & \\
\hline $\begin{array}{ll}K l & G\end{array}$ & 36 & 1.25 & 0.47 & 0.59 & 1 & & 0.59 & 0.499 & 32 & 15.97 & 9 & & & & & \\
\hline DKP1G & - & 0.8 & 2.25 & 1.80 & 1 & & 1.80 & 3.5 & 32 & 112.00 & 202 & & & & & \\
\hline Ta & 15 & 5.3 & 6.4 & 33.92 & 1 & & 33.92 & 0.318 & 26 & 8.27 & 280 & & & & & \\
\hline Qs $=$ & $1 / 3,6$ & ( a. & L. & $R$. & $\mathrm{H}$. & Ze. & $\Delta \mathrm{T})$ & & & Toplam= & 1248 & 7 & 0 & 5 & 1.12 & 1398 \\
\hline$Q s=$ & 0.277 & 3.00 & 29.70 & 0.90 & 2.43 & 1.20 & $32.00=$ & & & & & & & & & 2073 \\
\hline & & & & & & & & & & & & & & & & 3471 Watt \\
\hline
\end{tabular}

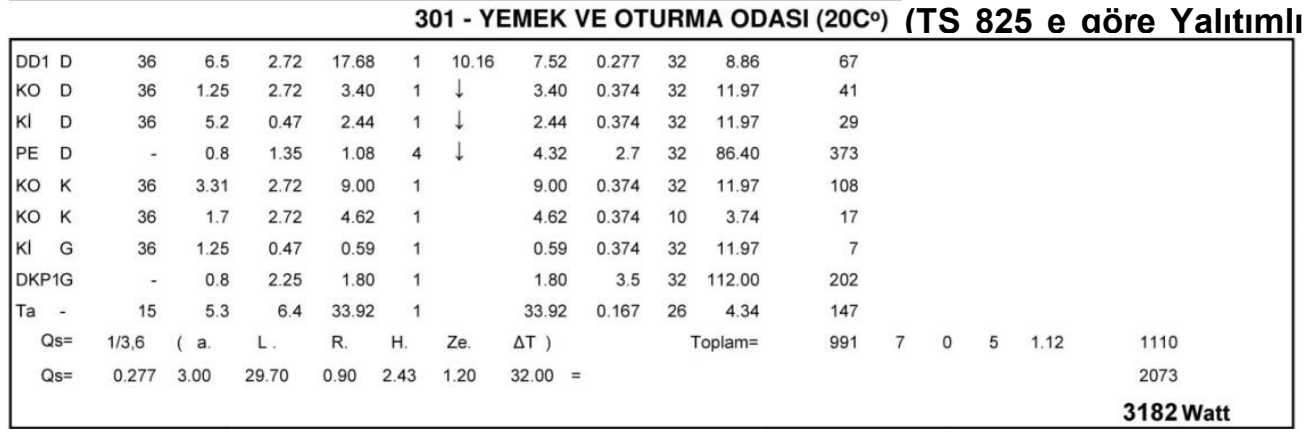


$\mathrm{Bu}$ işlemler diğer bütün hacimler için yalıtımsız hal, mevcut yalitımlı hal ve TS 825 standardina uygun yalıtımlı hale göre yapılarak bütün binaya ait 1sı kaybı değerleri belirlenmiş ve bütün binanın yalıtım açısından çalışılan bu üç durumu için Çevre ve Şehircilik Bakanlığı birim fiyatları kullanılarak yatırım maliyetleri ve buna bağlı olarak amortisman süreleri doğal gaz yakıtına göre mevcut yalıtımlı durum için denklem 4 te, TS 825'e göre yalıtımlı durum için denklem 5 te verilmiştir.

$$
\begin{aligned}
& \text { Amortisman süresi }=\frac{\text { MYDIYM-YDIYM }}{\text { YDYM-MYDYM }} \\
& \text { Amortisman süresi }=\frac{\text { TGYDIYM-YDIYM }}{\text { YDYM-TYDYM }}
\end{aligned}
$$

Denklem 4 ve 5 te verilen MYDIYM mevcut yalıtımlı durum için ilk yatırım maliyetini, YDIYM yalıtımsız durum için ilk yatırım maliyetini, YDYM yalıtımsız durum için yakıt maliyetini, MYDYM mevcut yalıtımlı durum için yakıt maliyetini, TGYDIYM TS825'e göre yalıtımlı durum için ilk yatırım maliyetini, TYDYM ise TS825'e göre yalıtımlı durum için yakıt maliyetini göstermektedir.

Örnek bina için TS 825 standartlarına göre yapılan hesaplamalar sonucu binanın yalitımsiz durumu, mevcut yalitımlı durumu ve TS $825^{\prime} \mathrm{e}$ göre yalıtımlı durumu için her kata ait 1sı kaybı değerleri Şekil 7'de verilmiştir. Örnek binanın yalıtımsız olması durumunda 161832 Watt'llk bir 1s1 kaybı gerçekleşmektedir. Gerçekleşen 1sı kaybı mevcut yalitımlı durumda 97982 Watt, TS 825 standardına uygun yalitım durumunda ise 79466 Watt değerini almaktadır.

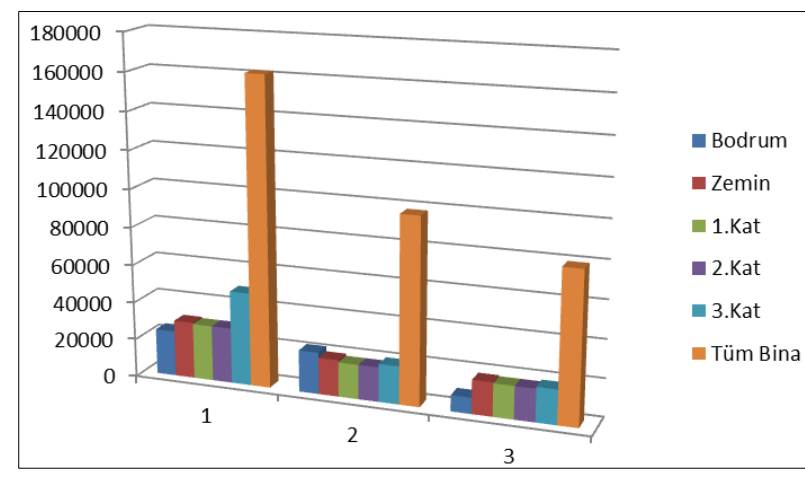

Şekil 7. Örnek binanın üç durumu için her kattaki ve tüm bina genelindeki 1s1 kayb1 1) Yalıtımsız durum 2) Mevcut yalitımlı durum 3) TS $825^{\prime}$ e göre yalıtımlı durum
Şekil 7'den görüleceği üzere mevcut yalıtımlı durumda yalıtımsız duruma göre $\% 39.5$ ' lik, TS 825 'e göre uygun yalıtıml durumda yalıtımsız duruma göre \%50.9' luk bir tasarruf sağlandığı tespit edilmiştir.

\section{Bulgular}

Örnek olarak incelenen lojman binasında yalıtımın sağladığı faydayı ve 1s1 köprülerini belirlemek amaciyla termal kamera görüntüleri alınmıştır. Görüntüler Testo 875 model termal kamera ile 2014 yılı Ocak ayında alınmış olup teknik özellikleri çizelge 2' de verilmiştir. Bina 2014 yılında dıştan mantolama yöntemiyle yalıtılmıştır. Binanın yalıtım yapılmadan önceki ve sonraki haline ait termal kamera görüntüleri Şekil 8 ve Şekil 10'da verilmiştir.

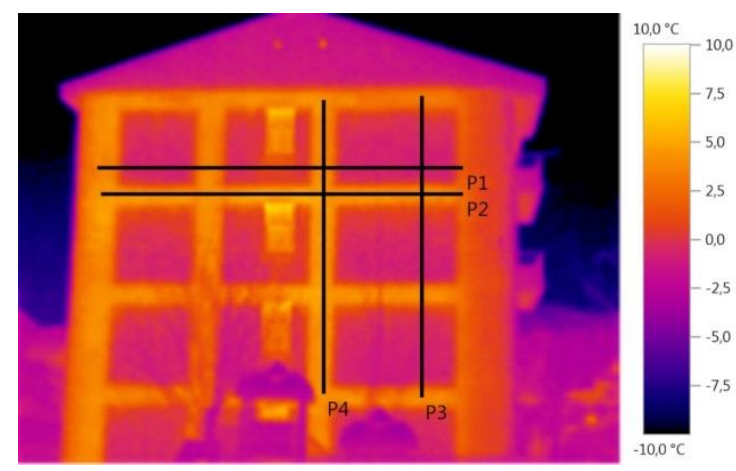

Şekil 8. Örnek binanın yalıtımdan önceki termal kamera görüntüsü üzerinde P1, P2, P3 ve P4 sıcaklık değişim doğrultularının gösterimi

Çizelge 2. Testo 875 termal kamerasına ait özellikler

\begin{tabular}{|l|l|}
\hline Görüntü yenileme oranı & $33 \mathrm{~Hz}$ \\
\hline Görüş alanı & $32^{\circ} \times 23^{\circ}$ \\
\hline Termal duyarlılık & $<50 \mathrm{mK}+30{ }^{\circ} \mathrm{C} \mathrm{de}$ \\
\hline İnfrared çözünürlük & $160 \times 120$ pixels \\
\hline Ölçüm aralığ 1 & -30 ile $+100^{\circ} \mathrm{C} ; 0$ ile $+350{ }^{\circ} \mathrm{C}$ \\
\hline
\end{tabular}

Ayrıca amortisman sürelerinin belirlenmesi amacıyla kazan, radyatör ve yalıtım malzemesi maliyetlerinden oluşan ilk yatırım maliyetleri yalıtımsız hal için 54114 € olup, mevcut yalıtımlı halde 68360 € ye çıkmakta, TS825 e göre ise 88067 £ olmaktadır. Yakıt olarak doğal gaz seçilmesi durumundaki yıllık yakıt maliyetleri de yalıtımsız hal için 38399 £, mevcut yalıtımlı hal için 24319 £ ve TS 825’e göre 19199 € olmaktadır. Belirlenen bütün bu değerlere göre amortisman süresi mevcut yalıtımlı halde 1.01 yil olurken TS 825 e göre 1.7 y1l olarak ortaya çıkmaktadır. Görüldüğü gibi TS 825 e göre amortisman süresi mevcut yalıtıml haldekinden daha yüksek çıkmaktadır, ancak yakıt maliyetleri ise daha düşük olmaktadır. 


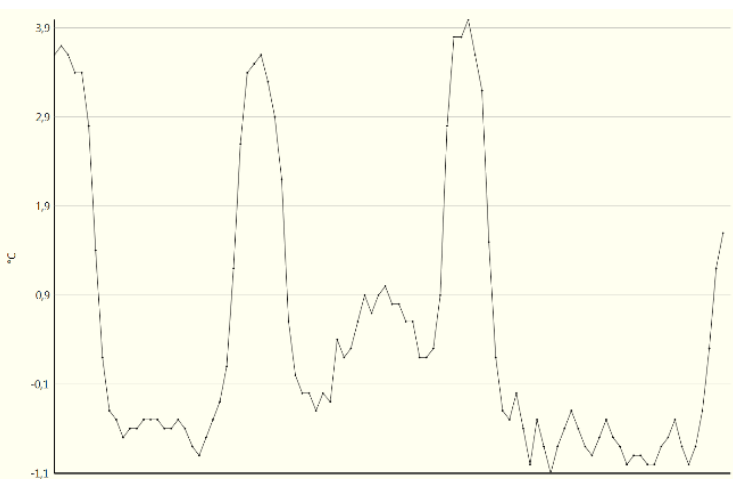

Minimum $-1.1^{\circ} \mathrm{C}$ Maksimum $4.0^{\circ} \mathrm{C}$ Ortalama $0.5^{\circ} \mathrm{C}$

a)

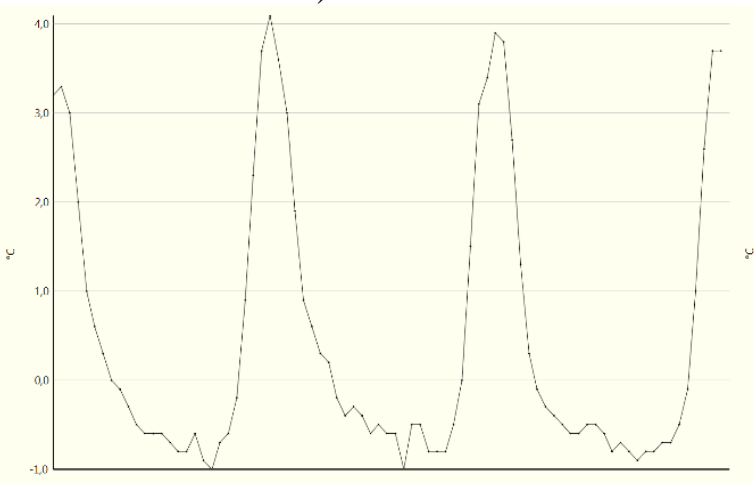

Minimum $-1.0^{\circ} \mathrm{C}$ Maksimum $4.1^{\circ} \mathrm{C}$ Ortalama $0.5^{\circ} \mathrm{C}$

c)

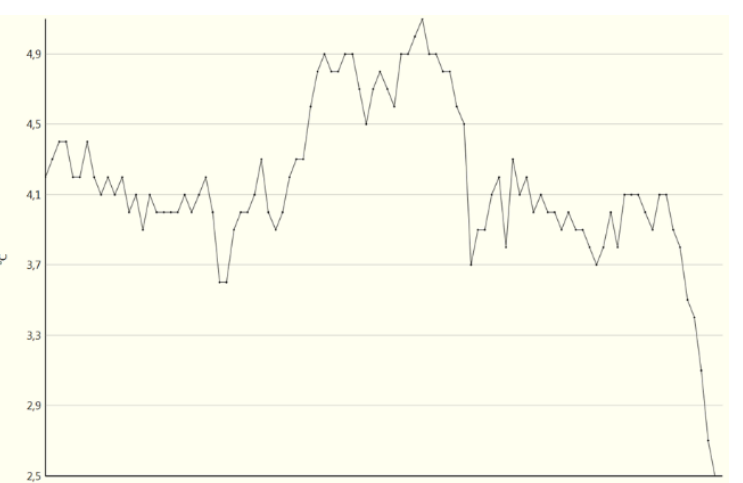

Minimum $2.5^{\circ} \mathrm{C}$ Maksimum $5.1^{\circ} \mathrm{C}$ Ortalama $4.2^{\circ} \mathrm{C}$

b)

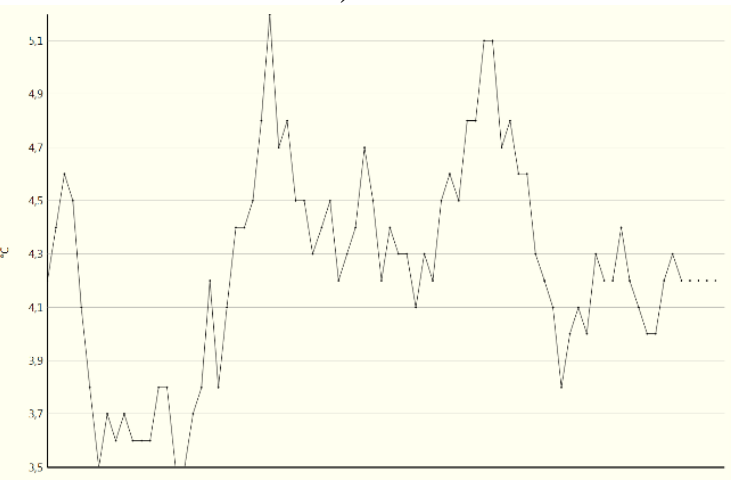

Minimum $3.5^{\circ} \mathrm{C}$ Maksimum $5.2^{\circ} \mathrm{C}$ Ortalama $4.2^{\circ} \mathrm{C}$

d)

Şekil 9. Farklı doğrultulardaki sıcaklık değiş̧imleri. a) P1, b) P2, c) P3, d) P4

Örnek binanın yalıtımdan önceki durumdaki termal kamera görüntüsünün verildiği Şekil 8 üzerinde yatay olarak P1 ve P2, düşey olarak P3 ve P4 sıcaklık değişim doğrultuları gösterilmektedir. Termal kamera görüntülerinden elde edilen Şekil 9'daki sıcaklık değişimleri incelendiğinde asıl 1S1 kaybının 1S1 köprüsü oluşturan kolon ve kirişlerde olduğu tespit edilmiştir. P1 ve P3 doğrultusundaki diş duvar, kolon ve kirişten oluşan yapı elemanlarının ortalama sicaklığının $0.5^{\circ} \mathrm{C}$ civarında olduğu, minimum ve maksimum sicaklıklarının da $-1.1^{\circ} \mathrm{C}$ ve $4.1^{\circ} \mathrm{C}$ olduğu görülmektedir. P2, P4 doğrultusundaki kolon ve kirişten oluşan yap1 elemanlarının ortalama sıcaklığ $4.2^{\circ} \mathrm{C}$ civarında olup minimum ve maksimum sicaklıkları da $2.5^{\circ} \mathrm{C}$ ve $5.2^{\circ} \mathrm{C}$ olmaktadır. Ayrıca şekilden kolon ve kirişlerdeki sıcaklığın $5.2^{\circ} \mathrm{C}$ 'a kadar çıktığı, dış duvarlarda ise sicaklığın $-1.1^{\circ} \mathrm{C}$ 'a kadar düşerek 1S1 kaybının bu kısımlarda en aza indiği görülmüştür. Şekil 9 da ayrıca P2 ve P4 doğrultusundaki sıcaklık hareketlerinde çok fazla değişmenin olmadığı; kolon, kiriş ve dış duvarlar gibi yap1 elemanlarının yatay ve düşey doğrultudaki sıcaklıklarının birbiri ile örtüştüğü, ayrıca P1-P3, P2-P4 başlangıç ve bitiş noktalarındaki sıcaklıkların birbirine yakınlaştığ görülmüştür.

Termal kamera görüntülerinden elde edilen Şekil 10'daki örnek lojman binasının dış duvar kabuğunun P3 doğrultusundaki kısmı yalıtım malzemesi ile kaplanmıştır. Şekil 11 de duvar kabuğunun yalıtılmış ve yalıtılmamış kısımları arasındaki fark açıkça görülmektedir.

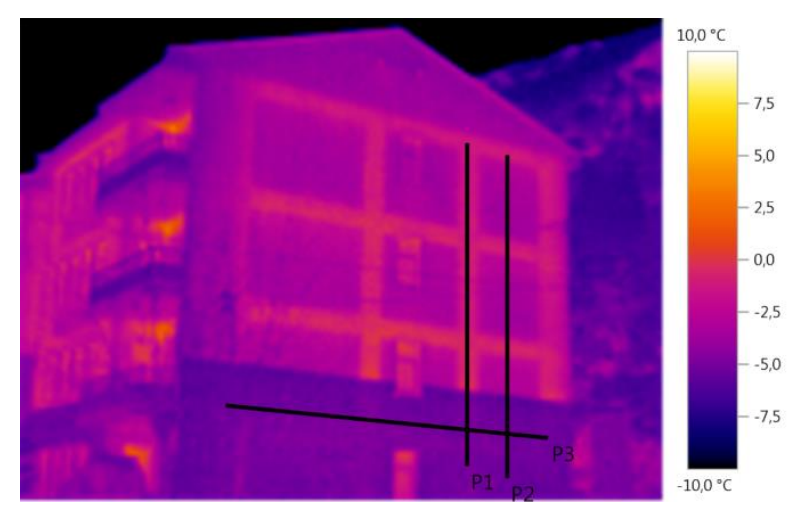

Şekil 10. Örnek binanın yalıtım sırasındaki durumu için termal kamera görüntüsü üzerinde P1, P2 ve P3 sıcaklık değişim doğrultularının gösterimi. 


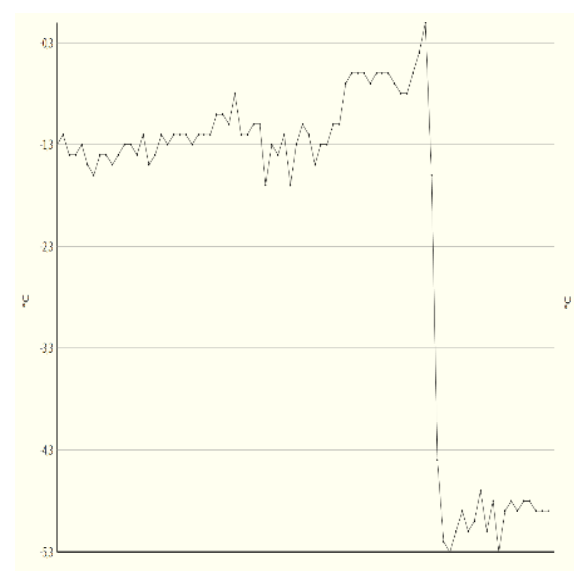

Minimum $-5.3^{\circ} \mathrm{C}$ Maksimum $-0.1^{\circ} \mathrm{C}$ Minimum $-5.7^{\circ} \mathrm{C}$ Maksimum $-0.6^{\circ} \mathrm{C}$ Ortalama $-2.0^{\circ} \mathrm{C}$

a)

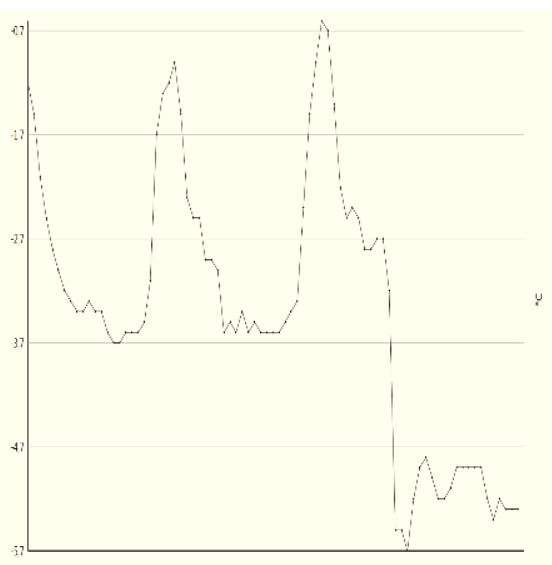

Ortalama $-3.4^{\circ} \mathrm{C}$

b)

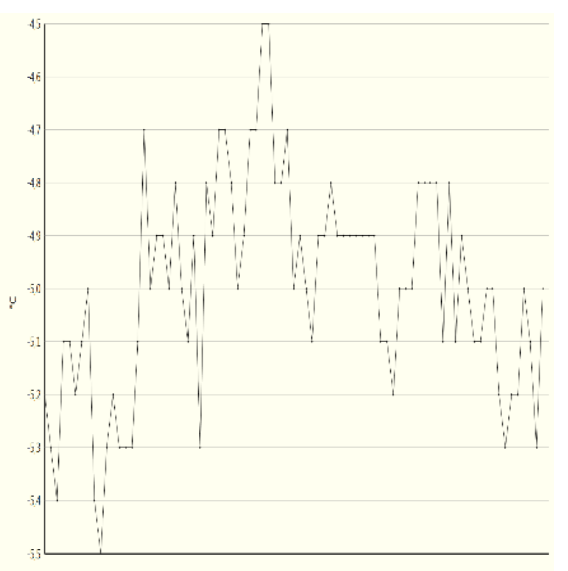

Minimum $-5.5^{\circ} \mathrm{C}$ Maksimum $-4.5^{\circ} \mathrm{C}$ Ortalama $-5.0^{\circ} \mathrm{C}$

c)

Şekil 11. Farklı doğrultulardaki sıcaklık değişimleri. a) P1 $\begin{array}{ll}\text { b) } \mathrm{P} 2 & \text { c) } \mathrm{P} 3\end{array}$

D1ş duvarın P1 ve P2 doğrultusunda çoğunluğu yalıtılmamış kısımda kalan bölümde homojen olmayan bir sıcaklık dağılımı olduğu, kolon ve kirişlerin 1 sı köprüsü oluşturduğu Şekil 10 ve 11 'de açıkça görülmektedir. Şekil 11'deki sıcaklık dağılım çizelgeleri incelendiğinde, P1 doğrultusundaki kolon, yalıtım malzemesinden oluşan yapı elemanlarının ortalama sıcaklığının $2{ }^{\circ} \mathrm{C}$ civarında olduğu, minimum ve maksimum sicaklıklarının da $-5.3^{\circ} \mathrm{C}$ ile $-0.1^{\circ} \mathrm{C}$ olduğu görülmektedir. P2 doğrultusundaki kiriş, diş duvar, yalıtım malzemesinden oluşan yap1 elemanlarının ortalama sicaklığının ise $-3.4^{\circ} \mathrm{C}$ civarında olduğu, minimum ve maksimum sicaklıklarının da $-5.7^{\circ} \mathrm{C}$ ve $-0.6^{\circ} \mathrm{C}$ olduğu görülmektedir. P3 doğrultusundaki yalıtım malzemesinden oluşan yapı elemanlarının ortalama sicaklığının $-5^{\circ} \mathrm{C}$ olduğu, minimum ve maksimum sicaklıklarının da $-5.5^{\circ} \mathrm{C}$ ve $-4.5^{\circ} \mathrm{C}$ olarak gerçekleştiği, dolayısıyla yalıtılmış kısmın sıcaklığın da fazla bir değişim olmadığ 1 görülmektedir. Şekil 11 incelendiğinde P1 doğrultusundaki kolon, yalıtım malzemesinden oluşan yapı elemanlarının yalıtım malzemesinin başlangıcına kadar ortalama $-1^{\circ} \mathrm{C}$ sabit sıcaklıkta devam ettiği, yalıtım malzemesinin başlangıcından itibaren ani bir düşüş gerçekleşerek $\quad-5^{\circ} \mathrm{C}$ civarına düştüğü görülmektedir. P2 doğrultusundaki kiriş, diş duvar, yalıtım malzemesinden oluşan yapı elemanlarının ise yalıtım malzemesinin başlangıcına kadar kiriş ve dış duvardan geçtiği için sıcaklığın $-0.7^{\circ} \mathrm{C}$ ile $-3.7^{\circ} \mathrm{C}$ arasında değiştiği, yalıtım malzemesinin başlangıcından itibaren ani bir düşüşle $-5^{\circ} \mathrm{C}$ civarına düştüğü ve yaklaşık sabit sıcaklıkta kaldığı görülmektedir. P3 doğrultusundaki yalıtım malzemesinden oluşan yap1 elemanları sıcaklığının $-5.5^{\circ} \mathrm{C}$ ile $-4.5^{\circ} \mathrm{C}$ arasında değiştiği ve diş duvar katmanın da en düşük sıcaklığa sahip olarak 1sı kaybının en az yaşandığı kısım olarak görülmektedir. Elde edilen sayısal değerlerden uygulanan yalıtımla birlikte 1s1 transferine karşı olan direncin arttığ1 ve dolayısıyla 1s1 transferinde önemli bir azalmanın meydana geldiği görülmektedir. Ayrıca bina içerisindeki ısının dışarıya hızla aktarıldığı 1S1 köprüleri de mantolamayla kapatıldığından bu noktalardaki 1sı transferinde de önemli düşüşler görülmüştür.

\section{Sonuçlar}

Elde edilen bulgulardan, yalitımsız binalara uygulanan yalıtımla birlikte ısı köprülerinin büyük bir oranda ortadan kalktığ 1 görülmüştür. Böylece 1sıtılan iç ortamdan dış ortama doğru olan 1s1 transferinde önemli bir azalma gerçekleştiği tespit edilmiştir. Yapılan yalıtımla birlikte duvar dış yüzeylerinde yaklaşık olarak homojen bir sıcaklık dağılımının ortaya çıktığı belirlenmiştir. TS $825^{\prime} \mathrm{e}$ göre yapılması gereken yalıtımın uygulamada tam olarak gerçekleştirilmediği, bu nedenle meydana gelen 1s1 kayıplarında artış olduğu tespit edilmiştir. Gümüşhane ili şartlarında incelenen örnek bina için yalıtımsız duruma göre yapılan karş1laştırmada mevcut yalıtımlı durum için yalıtımsız duruma göre $\% 39.5$ ' lik, TS 825 'e göre yapılması gereken yalıtım için yalıtımsız duruma göre \%50.9' luk bir tasarruf sağlanacağı tespit edilmiştir. Ayrıca amortisman süreleri değerlendirildiğinde TS 825 e göre yapılan yalıtım için amortisman süresinin biraz arttı̆̆ 1 , ancak yıllık yakıt tüketiminin azaldığı görülmüştür. Elde edilen bu değerler ışığında özellikle kışların uzun 
ve soğuk olduğu bölgelerde standartlara uygun yapılacak yalıtımla birlikte konutlardaki enerji ihtiyacının önemli oranda azalacağı öngörülmektedir.

\section{Kaynaklar}

Aktemur, C. ve Atikol, U., 2017. Optimum Insulation Thickness for the Exterior Walls of Buildings in Turkey Based on Different Materials, Energy Sources and Climate Regions. International Journal of Engineering Technologies-IJET, $3(2), 72-82$.

Balo, F., Uçar, A. ve İnallı, M., 2011. Yapıların Dış Duvarlarında Optimum Yalıtım Kalınlığının Üç Farklı Metodla Tespiti. X. Ulusal Tesisat Mühendisliği Kongresi, 273-286.

Buyruk, E., Fertelli, A. ve Karabulut, K., 2013. Farklı Yalıtım Uygulamalarının Is1 Kaybına Olan Etkilerinin Deneysel ve Sayısal İncelenmesi. Tesisat Mühendisliği - Sayı 136, 53-64.

Ertürk, M., 2016. Bina Dış Duvarlarında Farklı Yalıtım Malzemesi ve Hava Boşluğu Kulanımının, Birim Alandaki Enerji Tasarrufu ve Kişi Baş1 Emisyon Hesaplamalarında Yeni Bir Yaklaşım. Journal of The Faculty of Engineering and Architecture of Gazi University, 31(2), 395-406.

Ertürk, M., Keçebaş, A., Çay, Y., Daşdemir, A., Coşkun, C. ve Işık,E., 2018. Binalardaki Optimum Yalıtım Kalınlığının Enerji Tasarrufu Ve Kişi Başı Sera Gazı Emisyonlarına Etkisi: İzmir'de Bir Durum Çalışması The Effect On Energy Saving And Greenhouse Gas Emissions Per Person Of Optimum İnsulation. 14th International Combustion Symposium (INCOS2018) 25-27 April 2018, 348-356.

Gürel, A. E. ve Cingiz, Z., 2000. Farklı Dış Duvar Yapıları İçin Optimum Isı Yalıtım Kalınlığı Tespitinin Ekonomik Analizi. Sakarya University Journal of Science, 15(1), 75-81.

Karakaya, H., 2018. Farklı Duvar ve Yakıt Tiplerinde Optimum Yalıtım Kalınlığının Isıtma ve Soğutmada Tespiti ve Çevresel Etkileri. Fırat Üniversitesi Mühendislik Bilimleri Dergisi, 30(2), 193-202.

Karakoç, V.R., 2015. Çorum İlindeki Binalarda Kullanılan Farklı Türdeki Isı Yalıtım
Malzemelerinin Optimum Kalınlığının Hesaplanmas1, Yüksek Lisans Tezi, Hitit Üniversitesi Fen Bilimleri Enstitüsü. Çorum, $112 \mathrm{~s}$.

Kaynaklı, Ö. ve Yamankaradeniz, R., 2007. Isıtma Süreci ve Optimum Yalıtım Kalınlığı Hesabı, VII. Tesisat Mühendisliği Kongresi, İzmir, 187195.

Kon, O. ve Yüksel, B., 2016. Kamu Binalarının Isıtma Yüküne Göre Diş Duvarlarının Optimum Yalıtım Kalınlıkları ve Enerji Tüketimleri. Balıkesir Üniversitesi Fen Bilimleri Enstitüsü Dergisi, 15(1), 30-47.

Kürekci, N. A., Ağra, O. ve Emanet, O., 2009. Determination of Optimum Insulation Thickness for Different Climatic Zones of Turkey. In ASME 2009 International Mechanical Engineering Congress and Exposition (pp. 499-505). American Society of Mechanical Engineers.

Kürekçi, A., Bardakçı, A. T., Çubuk, H. ve Emanet, Ö., 2012. Türkiye'nin Tüm İlleri İçin Optimum Yalıtım Kalınlığının Belirlenmesi. Tesisat Mühendisliği, 131, 5-21.

Sezer, F. Ş., 2005. Türkiye'de Isı Yalıtımının Gelişimi ve Konutlarda Uygulanan Dış Duvar Isı Yalıtım Sistemleri. Uludağ Üniversitesi MühendislikMimarlık Fakültesi Dergisi, 10(2), 79-85.

Türkmen, M., 2016. Bina Kabuğunda Is1 Yalıtımı Uygulamalarının Yapısal Performansı Ve Etkinliğinin İstanbul'da Bir Alan Çalışması İle İncelenmesi. Doktora Tezi, İstanbul Teknik Üniversitesi Fen Bilimleri Enstitüsü, 255s.

Yaman, Ö., Şengül, Ö., Selçuk, H., Çalıkuş, O., Kara, İ., Erdem, Ş. ve Özgür, D., 2015. Binalarda Is1 Yalıtımı ve Isı Yalıtım Malzemeleri. Türkiye Mühendislik Haberleri (TMH), (487), 62-75.

URL-1,

http://www.eigm.gov.tr/File/?path=ROOT\%2f4 $\% 2$ fDocuments $\% 2 \mathrm{f} \% \mathrm{C} 4 \% \mathrm{~B} 0$ statistik\%20Rapor $\mathrm{u}$

\%2f2018\%20Ekim\%20Ay\%C4\%B1\%20Enerji \%20Raporu.pdf, 31 Aralık 2018.

URL-2,

http://www.resmigazete.gov.tr/eskiler/2008/08/2 0080826-7-1.doc, Ağustos 2016. 